\title{
EFFECTS OF PRE-INCUBATION LASER IRRADIATION ON HATCHABILITY AND SMALL INTESTINE ENZYMES ACTIVITY IN POST-HATCHED BROILER CHICKENS
}

\author{
J. GHIASI GHALEHKANDI ${ }^{1}$, J. HEYDARBEYGI ${ }^{2}$, Y. EBRAHIMNEZHAD ${ }^{2}$ \\ \& S. HASSANPOUR ${ }^{3}$ \\ ${ }^{1}$ Department of Veterinary Medicine, ${ }^{2}$ Department of Animal Science; Sha- \\ bestar Branch, Islamic Azad University, Shabestar, Iran; ${ }^{3}$ Section of Physio- \\ logy, Department of Basic Sciences, Faculty of Veterinary Medicine, Science \\ and Research Branch, Islamic Azad University, Tehran, Iran
}

\section{Summary}

Ghiasi Ghalehkandi, J., .J. Heydarbeygi, Y. Ebrahimnezhad \& S. Hassanpour, 2015. Effects of pre-incubation laser irradiation on hatchability and small intestine enzymes activity in post-hatched broiler chickens. Bulg. J. Vet. Med., 18, No 3, 227-238.

\begin{abstract}
The aim of this study was to investigate effects of short-term laser application on hatchability, died embryo in eggs and effects on post-hatch enzyme activity in different sections of small intestine (1, $10,30,50,70$ and $90 \%$ ) in broiler chickens at 21 and 42 days of age. Two experiments were carried out. In the first experiment, 900 fertilised eggs (Ross 308) were randomly divided into three experimental groups (three replications and 100 eggs per group), which were irradiated with laser (HeliumNeon) at 0,6 and $10 \mathrm{~mW}$ power respectively for $90 \mathrm{~s} ; 12 \mathrm{~h}$ prior to incubation. The eggs were randomly incubated at industrial hatcheries. At hatch day, rates of unfertilised eggs, hatched, unhatched, dead unhatched embryos were determined in different phase of incubation (1-6 and 7-18 days). In the second experiment, 234 one-day-old chickens where allocated into three experimental groups based on irradiation laser levels (three replications and 26 birds per group). At post hatch days 21 and 42 , six birds were randomly selected from each group, slaughtered and various sections of small intestine $(1,10,30,50,70$ and $90 \%)$ were sampled to evaluate alkaline phosphates (ALP), leucine aminopeptidase (LAP) and sucrase activities. According to the results, laser irradiation had no significant difference on egg hatchability, unfertilised eggs, unhatched died and died embryos $(\mathrm{P}>0.05)$. A significant difference was observed in small intestine LAP and ALP levels at days 21 and 42 $(\mathrm{P}<0.05)$. These results suggested that laser irradiation altered small intestine enzyme activity in broilers.
\end{abstract}

Key words: alkaline phosphatase, broiler chicken, hatchability, laser irradiation, leucine amino peptidase, sucrase 


\section{INTRODUCTION}

Recently, the effects of laser irradiation on animal reproduction, productivity as well as food safety were investigated (Yakimenko et al., 2002; Iaffaldano et al., 2005; Yakovlev et al., 2007; Iaffaldano et al., 2010; Maktabi et al., 2011). New protocols have been suggested by researchers for laser therapy in medicine. Dosedependent laser irradiation has both positive and negative biological effects. Formerly, it was reported that laser irradiation increased cell mitotic and proliferation processes (Mester \& Mester, 1985; Yakovlev et al., 2007). Also, it was reported that laser therapy increased anti-oxidant enzymes levels than other type of enzymes (Yakimenko et al., 2002). Conversely, it was suggested that low-intensity laser irradiation had no efficacy. Laboratory studies indicated that gallium-aluminumarsenide laser irradiation was unable to stimulate cell proliferation, migration and wound healing (Moore et al., 2005). Helium-neon laser beam was shown to stimulate gametic, embryonic cells and sperm motility in birds (Iaffaldano et al., 2005). Additionally, irradiation improved fibroblasts mitosis and growth factor production in chickens (Lubart et al., 1992; Yu et al., 1994). Yakimenko et al. (2002) reported that hatchability of irradiated egg increased and mortality rate decreased by using He-Ne laser $\left(0.1 \mathrm{~mW} / \mathrm{cm}^{2}\right.$ for $\left.60 \mathrm{~s}\right)$ in meat and layer-type chickens, respectively.

It is proved that intestine villi and epithelial cell morphology are indispensable in intestine growth and function (Ruttanavut et al., 2009). It is well known that a correlation exists between luminal cell proliferation and its turnover rate. Narrow and long intestinal villi are an indicator of rapid proliferation of crypts and short turnover rate of these epithelial cells whereas high villi indicate active intestine villi function with long turnover rate (Nordstrom \& Dahlqvist, 1973; Langhout et al., 1999). With this regard, Abolhassani et al. (2010) reported that $\mathrm{He}-\mathrm{Ne}$ laser irradiation had positive effects on villus height, crypts depth and villus height/crypt depth ratio in various sections of small intestine in broilers. The effects of laser irradiation have not been completely studied in chickens (Yakovlev et al., 2007). Leucine amino peptidase is one of the dominant peptidases in small intestine villus which degrades long-chain peptides of proteins to smaller peptides and amino acids to enhance nutrient absorption efficacy in animals (Ghiasi Ghalehkandi et al., 2009). Alkaline phosphatase (ALP) is another prominent enzyme from the group of catalytic enzymes, frequently distributed in brush border of intestinal mucosal cytosol, degrading phosphate esters and separating phosphoric acid molecules (Ghiasi Ghalehkandi et al., 2012). It is reported that low-level laser therapy significantly diminished carbon tetrachloride-increased ALP of rat liver (Oliveira-Junior et al., 2013).

So far, there are few literature reports related to the effects of low-power laser irradiation on gastrointestinal enzymes in birds. Therefore, the recent study was designed to investigate the possible effects of pre-incubation laser irradiation ( $\mathrm{He}-\mathrm{Ne})$ on egg fertility and hatchability. We also designed a second experiment to follow out the influence of laser irradiation on post hatch small intestinal function through the effects of He-Ne laser irradiation on enzyme activity (ALP, LAP and sucrase) in different sections of small intestine of post hatch broilers at 21 and 42 days of age. 


\section{MATERIALS AND METHODS}

\section{Laser irradiation}

A single mode continuous (He-Ne), 633 $\mathrm{nm}$ wavelength laser irradiation (red light) made by Bonab Nuclear Research Institute (East Azarbayjan, Iran) was used. All doses of laser irradiation were calculated based on previous and pilot studies (Yakimenko et al., 1997; 2002).

\section{Experiment 1}

This experiment was performed at the Bonab Animal and Agriculture Nuclear
Research Center, East Azarbayjan, Iran. One thousand and eight-hundred fertilised eggs were purchased from Eshragh Co., Iran. Nine-hundred fertilised eggs (Ross 308) were selected, sorted, graded and randomly divided into three experimental groups (three replications and 100 eggs per group). Experimental eggs were irradiated with $\mathrm{He}-\mathrm{Ne}$ laser irradiation (red light) at zero, 6 and $10 \mathrm{~mW}$ power, 633 $\mathrm{nm}$ wavelength for $90 \mathrm{~s}, 12 \mathrm{~h}$ prior to incubation. The irradiation procedure was performed under darkened conditions (Yakimenko et al., 2002). Eggs collected

Table 1. Ingredient and nutrient compositions of experimental diets (1-42 days of age)

\begin{tabular}{lccc}
\hline Ingredient (\%) & $\begin{array}{c}\text { Starter } \\
\text { (1-21 days of age })\end{array}$ & $\begin{array}{c}\text { Grower } \\
(22-35 \text { days of age })\end{array}$ & $\begin{array}{c}\text { Finisher } \\
(36-42 \text { days of age })\end{array}$ \\
\hline Corn grain & 52.01 & 58.75 & 71.1 \\
Soybean meal (44\%) & 35.50 & 28.35 & 25.94 \\
Wheat & 5.50 & 8 & 0 \\
Barley & 1.53 & 0 & 0 \\
Oil & 1.75 & 1 & 0.1 \\
DCP & 1.4 & 0 & 0 \\
Oyster & 1.27 & 0.77 & 0.76 \\
Bone meal & 0 & 2.14 & 1.8 \\
Mineral premix & 0.25 & 0.25 & 0.25 \\
Vitamin premix & 0.25 & 0.25 & 0.25 \\
DL-methionine & 0.24 & 0.12 & 0.02 \\
Lysine monohydro- & 0 & 0.08 & 0 \\
chloride & & & 0.1 \\
Salinomycin & 0.1 & 0.1 & 0.02 \\
Salt & 0.02 & 0.02 & \\
Calculated analysis & & & 3032 \\
ME, kcal/kg & 2900 & 2941 & 17.05 \\
Crude protein (\%) & 20.84 & 18.38 & 0758 \\
Calcium (\%) & 0.9063 & 1.02 & 0.285 \\
Available phosphorus & 0.4028 & 0.4 & 177.77 \\
ME/protein & 139.130 & 160 & 2.66 \\
Calcium/phosphorus & 2.22 & 2.56 & \\
\hline
\end{tabular}

$\mathrm{DCP}=$ dicalcium phosphate, $\mathrm{ME}=$ metabolisable energy. Per $2.5 \mathrm{~kg}$ feed, the mineral supplement contains $99,200 \mathrm{mg}$ magnesium, 84,700 $\mathrm{mg}$ zinc, 50,000 mg iron, 10,000 mg copper, $990 \mathrm{mg}$ iodine, $200 \mathrm{mg}$ selenium, $250,000 \mathrm{ml} \mathrm{g}$ choline chloride. Per $2.5 \mathrm{~kg}$ feed, the vitamin supplement contains $900,000 \mathrm{IU}$ of vitamin A, 200,000 IU of vitamin $\mathrm{D}_{3}, 190,00 \mathrm{IU}$ of vitamin E, 2,000 $\mathrm{mg}$ vitamin $\mathrm{K}_{3}$, $18,050 \mathrm{mg}$ vitamin $\mathrm{B} 1,49,000 \mathrm{mg}$ vitamin $\mathrm{B}_{2}, 9,800 \mathrm{mg}$ vitamin $\mathrm{B}_{3}, 29,650 \mathrm{mg}$ vitamin $\mathrm{B}_{5}, 2,940$ mg vitamin $B_{6}, 1,000 \mathrm{mg}$ vitamin $B_{9}, 15 \mathrm{mg}$ vitamin $B_{12}, 100 \mathrm{mg}$ biotin, 190,000 mg choline chloride, $1,000 \mathrm{mg}$ antioxidant. 
on plastic flats, cooled to room temperature $\left(18.6^{\circ} \mathrm{C}\right.$, humidity $\left.75 \%\right)$ were randomly incubated in an automated incubator $\left(37.2^{\circ} \mathrm{C}\right.$, humidity $\left.60 \%\right)$ and at day 18 were transferred in industrial hatcheries $\left(37.5{ }^{\circ} \mathrm{C}\right.$, air speed $0.2 \mathrm{~m} / \mathrm{sec}$, humidity $75 \%$ ). Egg sets were candled twice during incubation to remove infertile and dead embryo eggs. On hatch day, rates of unfertilised eggs, hatched eggs, unhatched eggs, dead embryos during different phase of incubation (1-6 and 7-18 days) and unhatched dead eggs were determined.

\section{Experiment 2}

Two-hundred and thirty four of hatched chickens from experiment one were randomly allocated into three experimental groups (completely randomised design) based on irradiation laser levels and transferred into heated batteries (three replications and 26 birds per group) with continuous lighting at temperature $22 \pm 1{ }^{\circ} \mathrm{C}$ with $50 \%$ humidity, on litter floor (Olanrewaju et al., 2006). Chickens received diets (starter, grower and finisher) formulated using User Friendly Feed Formulation Done Again (UFFDA) (Pesti et al., 1992). Chemical composition of experimental diets is presented in Table 1. During the study all birds had free access to food and fresh water.

At 21 and 42 days of age, three hours prior to intestinal sample collection, birds were deprived from food. Six birds were randomly selected from each replication, slaughtered and the entire gastrointestinal tract was removed. Various sections of small intestine - A, B, C, D, E and F (1, $10,30,50,70$ and $90 \%$, respectively) were sampled (a 7-cm sample was taken), rinsed with phosphate buffer solution (PBS, $\mathrm{pH}=7$ ) and stored at $-80{ }^{\circ} \mathrm{C}$ (Ghiasi Ghalehkandi et al., 2014). All experimental procedures were performed according to the Guide for the Care and Use of Laboratory Animals by the National Institutes of Health (USA) and the current laws of the Iranian government.

\section{Enzyme assays}

In the laboratory, $0.01 \mathrm{~g}$ of small intestine mucosa was weighed using a sensitive scale (OHAUS) and along with $10 \mathrm{~mL}$ PBS was homogenised using sonic vibracell device (VCX 130 TE USA) to cell degradation and achieve brush border total protein (TP), ALP, LAP and sucrase activity. Total protein level was determined according to the pyrogallol method (Wantanabe et al., 1986); LAP level according to Nigel et al. (1964) and Hill (1971); sucrase enzyme activity according to the Dahlqvist procedure (1964) and ALP activity - colorimetrically by measuring the rate of $\mathrm{p}$-nitrophenol formation (Forstner et al., 1968) on an auto analyzer (Mindray BS-200, Germany). Enzyme activities of samples were divided to the total protein concentrations and calculated as IU per g protein (Teshfam, 1984).

\section{Statistical analysis}

Data were analysed by multivariate analysis of variance by the linear model using SAS statistical software (SAS v.9.1). Comparative analysis of the means of treatments was performed using Duncan's multiple tests at $\mathrm{P}<0.05$ as significant difference between treatments.

\section{RESULTS}

The effect of short-term laser irradiation on hatchability, unfertilised eggs, unhatched dead and dead embryos in chickens is presented on Fig. 1. As seen from the figure, there was no significant difference on studied hatchability traits of eggs after laser irradiation (6 and $10 \mathrm{~mW}, 90 \mathrm{~s}$ ) 


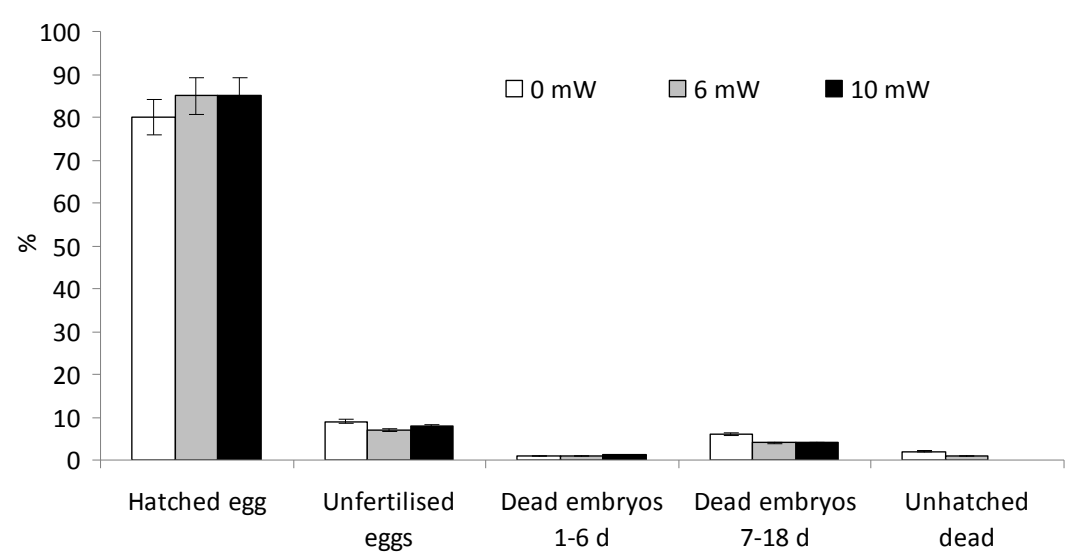

Fig. 1. Effects of different levels of laser irradiation (He-Ne, $90 \mathrm{sec}$.) on hatchability, unfertilised eggs, unhatched dead and dead embryos during different days of incubation in broiler chickens.

in experimental groups compared to the control group $(\mathrm{P}>0.05)$.

In experiment 2 , ALP activity was significantly increased after $6 \mathrm{~mW} \mathrm{He}-\mathrm{Ne}$ irradiation on $1 \%$ section of small intestine in broilers aged 21 days $(\mathrm{P}<0.05)$. Furthermore, a significant difference was observed between ALP activity of irradiated groups in various small intestine sections $(30,50$ and $70 \%)$ in 21-day-old broilers $(\mathrm{P}<0.05)$, but there was no difference compared to controls $(\mathrm{P}>0.05)(\mathrm{Ta}-$ ble 2). It seemed that $6 \mathrm{~mW}$ pre-incubation $\mathrm{He}-\mathrm{Ne}$ irradiation had a better effect on small intestine ALP activity in birds. Also, there was a significant decrease in ALP activity in 50 and $90 \%$ of small intestine in $10 \mathrm{~mW} \mathrm{He}-\mathrm{Ne}$ irradiated birds at 42 days of age $(\mathrm{P}<0.05)$. In addition, no significant differences were observed in ALP activity in the other sections of small intestine $(\mathrm{P}>0.05)$ (Table 2$)$.

A significant difference was detected in small intestine LAP activity (30\% of small intestine length) in $6 \mathrm{~mW} \mathrm{He-Ne}$ group vs controls $(\mathrm{P}<0.05)$. Moreover, the same results were obtained for LAP acti- vity in different sections of small intestine length (50, 70 and 90\%) using $10 \mathrm{~mW}$ $\mathrm{He}-\mathrm{Ne}$ for $90 \mathrm{~s}$ in 21-day-old broilers $(\mathrm{P}<0.05)$ (Table 3). According to the data, at 42 days of age a significant decrease was found out on LAP activity in different sections of small intestine $(10,30,50,70$ and 90) in birds receiving $10 \mathrm{~mW} \mathrm{He-Ne}$ laser irradiation $(\mathrm{P}<0.05)$ (Table 3$)$. There was no significant difference between the 6 $\mathrm{mW}$ group and the control group $(\mathrm{P}>0.05)$. It seemed that $10 \mathrm{~mW} \mathrm{He}-\mathrm{Ne}$ preincubation irradiation had an adverse effect on small intestine LAP activity in birds.

In this study, there was no significant difference between sucrase enzyme activity in various sections of small intestine $(1,10,30,50,70$ and 90 small intestine length) in experimental birds compared to control group both at 21 and 42 days of age $(\mathrm{P}>0.05)$ (Table 4).

\section{DISCUSSION}

To our knowledge, this is the first study to investigate the possible effects of $\mathrm{He}-\mathrm{Ne}$ laser irradiation on small intestine enzyme 
Effects of pre-incubation laser irradiation on hatchability and small intestine enzymes activity in ....

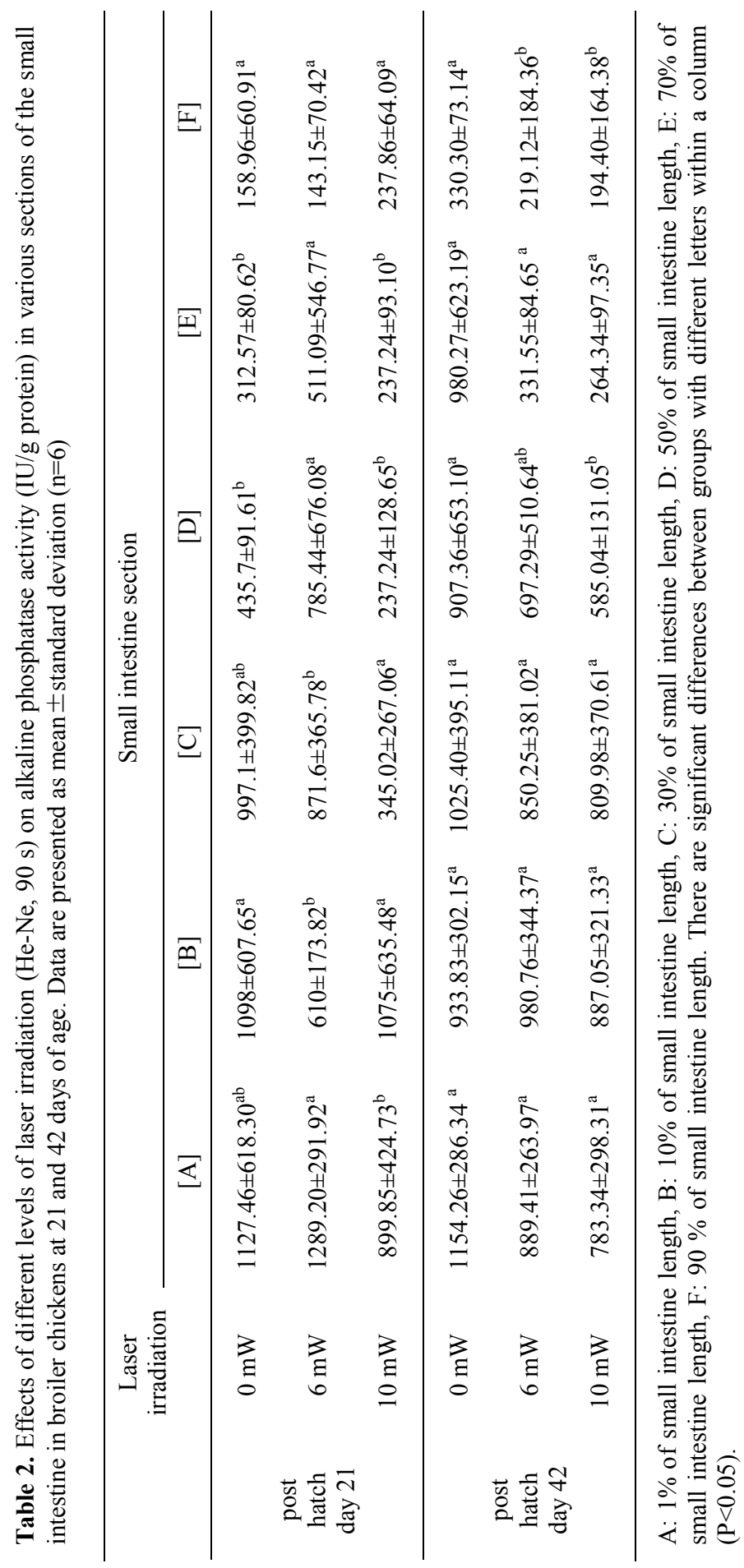


J. Ghiasi Ghalehkandi, J. Heydarbeygi, Y. Ebrahimnezhad \& S. Hassanpour

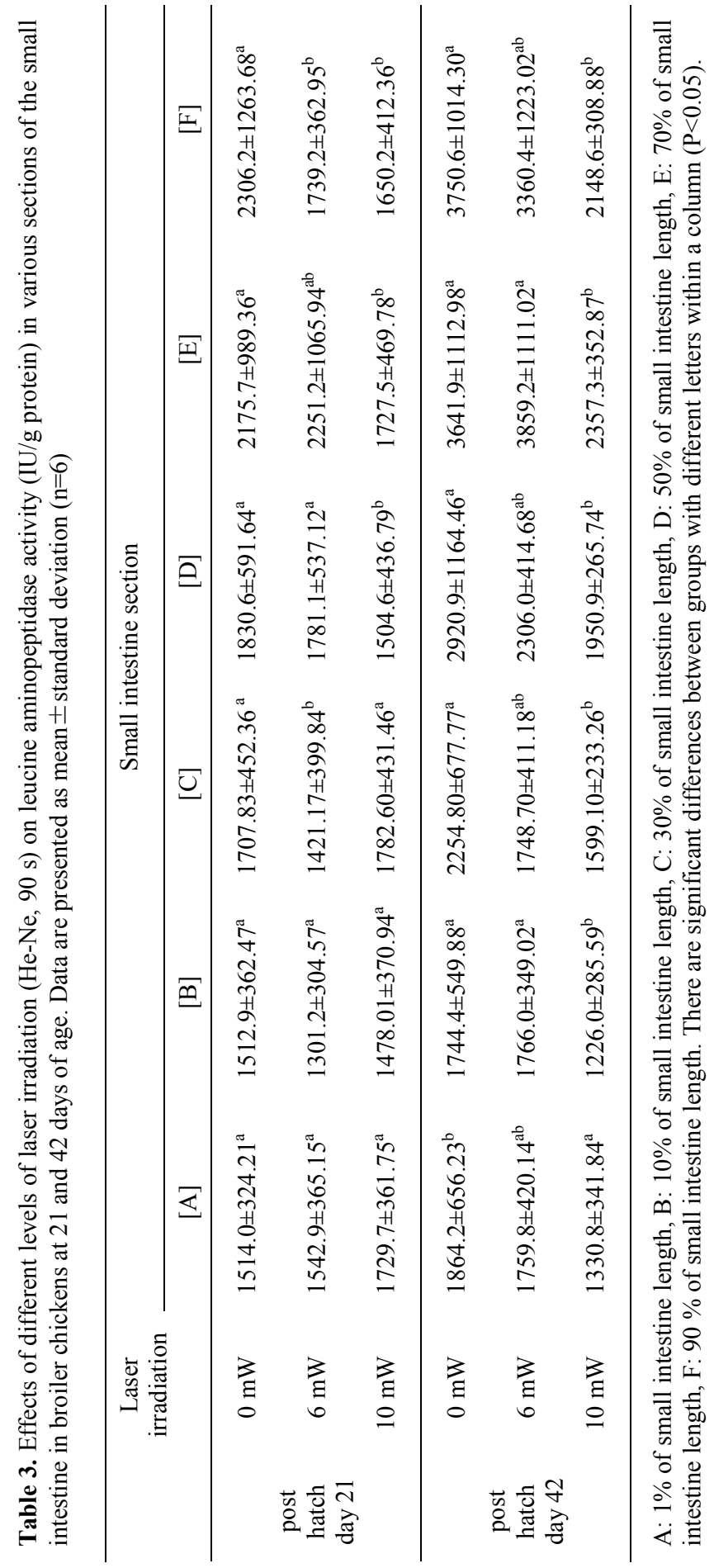

BJVM, 18, No 3 
Effects of pre-incubation laser irradiation on hatchability and small intestine enzymes activity in ....

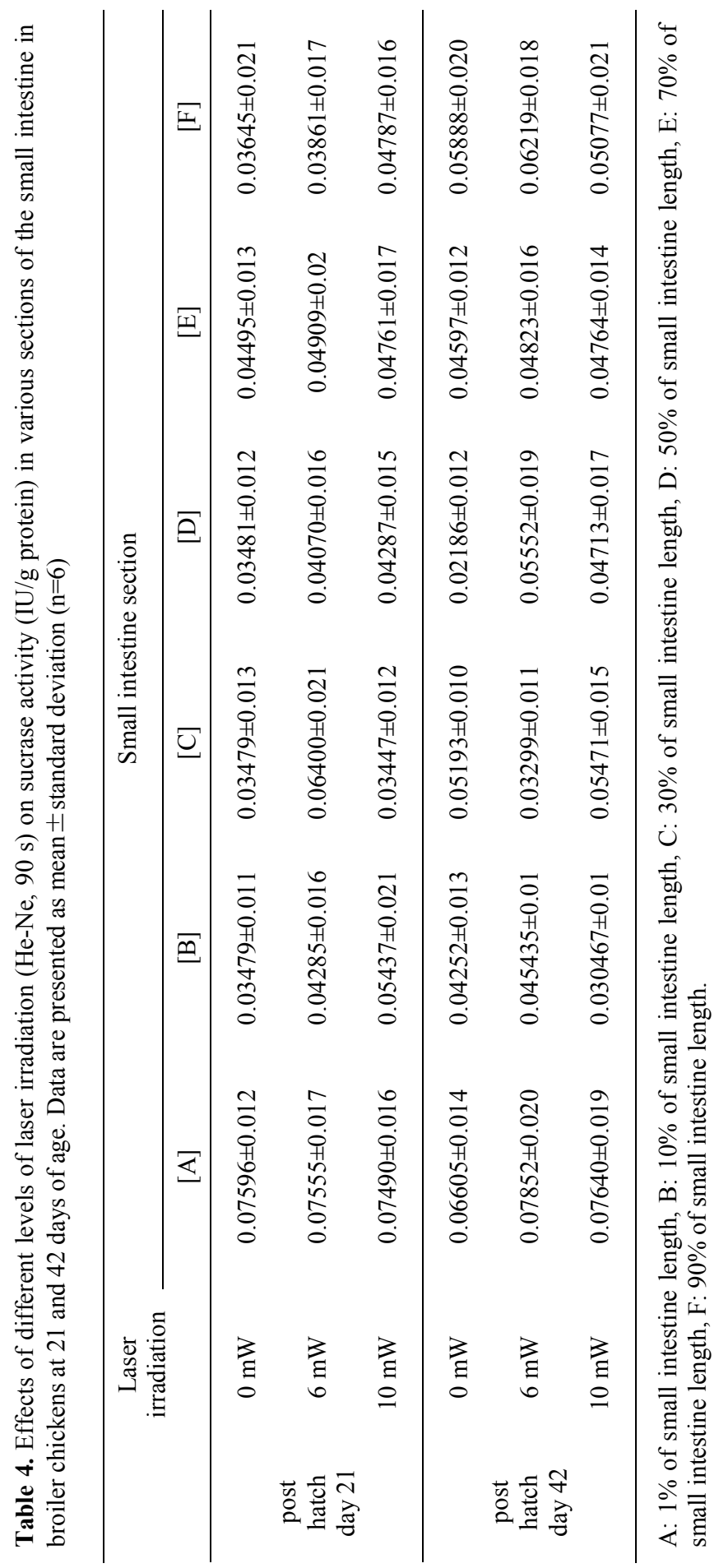


activity in broilers. According to the obtained results from experiment 1 (Fig. 1), laser irradiation $(6$ and $10 \mathrm{~mW}, 90 \mathrm{~s})$ had no effects on hatchability, unfertilised eggs, unhatched dead and dead embryo rates in broiler eggs. Previously, it is reported that $0.1 \mathrm{~mW} / \mathrm{cm}^{2} \mathrm{He}-\mathrm{Ne}$ laser irradiation significantly improved hatchability and decreased mortality rates in broiler eggs (Yakimenko et al., 2002). Moreover, Ivanov et al. (1989) was reported increased hatchability rate consequently to pre-incubation $\mathrm{He}-\mathrm{Ne}$ laser irradiation. Also, similar findings were reported on duck eggs by Melnikova et al. (1985). According to our data, irradiation tended to improve hatchability and decreased mortality rate but the effects were not significant. Low-level red light laser irradiation increases cell proliferation. It seems that irradiation increases $\mathrm{Fe}^{3+}$ absorption from yolk sack during the embryonic phase; promotes haemoglobin synthesis and improves subsequent survival (Yakimenko et al., 2002). An alternative mechanism was suggested for the mitogenic effects of low power laser irradiation - it is supposed that the infrared light can be absorbed through the mitochondrial respiratory chain to promote cellular proliferation via stimulating adenosine triphosphate or cyclic AMP, inducing photo-activation of calcium channels (Moore et al., 2005; Gao \& Xing, 2009).

According to our results, a significant increase was observed in ALP activity using He-Ne irradiation in various sections of small intestine (30, 50 and $70 \%)$ in broilers at 21 days of age. Low-energy laser irradiation has positive effects on bone formation, osteoblast proliferation and ALP activity (Ninomiya et al., 2003). According to evidence, the lumen of broiler's embryo is ALP free during the first week of embryonic life and it gently increases form day 9 (Moog, 1950). In this regard, Ninomiya et al. (2003) reported that low level laser therapy amplified cell proliferation rate and bone ALP activity in rat. Conversely, a decrease was detected on small intestine ALP activity in $10 \mathrm{~mW} H e-\mathrm{Ne}$ irradiated birds on the $42^{\text {nd }}$ post hatch day. There is a difference in duodenal, jejunal and ileal villus growth rate in broilers. After hatching, duodenal villi growth rate is much faster than that of jejunal and ileal villi (Obst \& Diamond, 1992; Shin et al., 2013). Dynamic cell proliferation increases villus number (Antheony et al., 1999). A range of factors affects small intestine villi growth rate and secretion e.g. age, food deprivation, luminal microflora, chemicals and irradiation (Ghiasi Ghalehkandi et al., 2011; Ouf et al., 2012). Additionally, recent findings suggest that a prominent physiological effect of low power laser irradiation is cell proliferation. In mammalian cells, low power laser irradiation amplifies cell proliferation by stimulating signal-regulated protein kinase, growth-factor-induced proliferation e.g. epidermal growth factor (EGF) stimulation or GTPase Ras protein, the Raf-1, the mitogen-activated protein kinase (MAPK) pathways (Gao \& Xing, 2009). With this regard, Abolhassani et al., (2010) reported that the application of $10 \mathrm{~mW} \mathrm{He}-\mathrm{Ne}$ laser for $90 \mathrm{~s}$ significantly increased villous length and crypt depth in irradiated broiler eggs at post hatched day 42. Also, similar findings were reported in rats (Carr et al., 1996). To our belief, laser irradiation was able to improve small intestine secretory cell proliferation which caused increased digestive enzyme production. In this study, a significant decrease was found out on LAP activity in different sections of small intestine in birds receiving $10 \mathrm{~mW} \mathrm{He}-\mathrm{Ne}$ laser irradiation. Huge villi height and excessive 
mitosis in intestine indicate active function of intestinal villi. On the other hand, the narrow and long intestinal villus is an emblem of rapid crypt proliferation. During cell evolution, these cells rapidly migrate to villus apex (Langhout et al., 1999; Awad et al., 2008). Rapid cell proliferation through multipotent stem cells in the crypts of Lieberkuhn, increases terminally differentiated cells which anatomically are more columnar absorptive cells interspersed with minute secretory cells (Van Der Flier \& Clevers, 2009). According to evidence and our observations it seems that laser irradiation stimulated intestinal cell proliferation rate and decreased cell turnover rate which results in diminished enzyme secretion in broilers (Nordstrom \& Dahlqvist, 1973; Langhout et al., 1999). The suggested mechanism is that light laser stimulates cyclic adenosine monophosphate elevation and increases both DNA and RNA synthesis which may terminate to increase enzyme secretion (Gao \& Xing, 2009). To our knowledge, there is no former study on the effects of laser irradiation on post-hatched intestinal enzyme activity in broilers, so there are no previous reports investigating the effects of laser therapy on small intestine enzyme activity to compare our results with. It seems that laser irradiation enhanced small intestine secretory cell number and increased digestive enzyme production. So laser treatment helped promoting digestion and absorption functions and subsequently, improves bird's efficacy for better nutrients utilisation, hence faster growth rate and/or production. Also, it may decrease nutritional costs.

Finally, we recommend further investigations to clarify effects and/or side effects of pre-incubation laser irradiation of eggs on hatchability and post-hatched small intestine enzymes activity in broiler chickens in order to distinguish their potential for use in clinical trials.

\section{REFERENCES}

Abolhasani, H., J. Ghiasi Ghalehkandi, A. Ahmadzadeh \& J. Heidarbeigi, 2010. The effect of helium neon laser irradiation on the morphology of small intestine of hatched broiler chicks. Journal of Comparative Pathobiology, 4, 515-520 (in Persian).

Antheony, C., J. Nguyen \& A. Griffian, 1999. In vitro and in vivo evaluation of effects of sodium caprate on enteral peptide absorption and on mucosal morphology. International Pharmacology, 191, 15-24.

Awad, W., K. Ghareeb \& J. Böhm, 2008. Intestinal structure and function of broiler chickens on diets supplemented with a synbiotic containing Enterococcus faecium and oligosaccharides. International Journal of Molecular Science, 9, 2205-2216.

Carr, K. E., J. S. Mccullough, R. A. Hazzard, S. P. Hume \& A. C. Nelson, 1996. Morphological Profiles of neutron and $\mathrm{X}$ irradiated small intestine. Journal of $R a$ diation Research, 37, 38-48.

Dahlqvist, A., 1964. Method of assay of intestinal disaccaridases. Analytical Biochemistry, 7, 18-25.

Forstner, G. G., S. M. Sabesin \& K. J. Isselbacher, 1968. Rat intestinal microvillus membranes-purification and biochemical characterization. Biochemistry Journal, 106, 381-390.

Gao, X. \& D. Xing, 2009. Molecular mechanisms of cell proliferation induced by low power laser irradiation. Journal of Biomedical Science, 16, 1-16.

Ghiasi Ghalehkandi, J., M. Teshfam, K. Nazer Adl, R. Salamatdoost Nobar, Y. Ebrahimnejad \& A. Gorbani, 2009. Effects of different levels of perlite on lucine aminopeptidase mucosal enzymes activity small intestine of broiler chickens. American- 
Eurasian Journal of Agricultural and Environmental Science, 6, 480-484.

Ghiasi Ghalehkandi, J., M. R. Valil, Y. Ebrahimnazhad, R. Salamatdoust Nobar, H. Karamouz \& M. Nazeri, 2011. Effect of different levels of perlite on performance of broiler chicks. Advances in Environmental Biology, 5, 776-779.

Ghiasi Ghalehkandi, J., M. Kumar, Y. Ebrahimnezhad \& R. Beheshti, 2012. In ovo administration of ghrelin and subsequent intestinal alkaline phosphatase (ALP) activity in broiler chickens. Advances in Bioresearch, 3, 9-13.

Ghiasi Ghalehkandi, J., S. Hassanpour, Y. Ebrahimnezhad, R. Beheshti \& N. MaheriSis, 2014. Intestinal morphography of broilers fed diets supplemented with perlite. Journal of the Hellenic Veterinary Medical Society, 65, 99-108.

Hill, H. Z., 1971. Enzyme kinetics in mammalian cells. 3. Regulation of activities of galactokinase, galactose-1-phosphate uridyl transferase and uridine diphosphogalactose-4-epimerase in human erythrocytes. The Journal of Cellular Physiology, 78, 419-430.

Iaffaldanoa, N., A. Meluzzi, A. Manchisi \& S. Passarella, 2005. Improvement of stored turkey semen quality as a result of $\mathrm{He}-\mathrm{Ne}$ laser irradiation. Animal Reproduction Science, 85, 317-325.

Iaffaldanoa, N., M. Pina Rosatoa, G. Paventib, R. Pizzutob, M. Gambacortaa, A. Manchisia \& S. Passarella, 2010. The irradiation of rabbit sperm cells with $\mathrm{He}-\mathrm{Ne}$ laser prevents their in vitro liquid storage dependent damage. Animal Reproduction Science, 119, 123-129.

Ivanov, N., D. Chotinski \& S. Aleksandrov, 1989. Effect of laser irradiation of eggs before incubtion on hatching. Poultry $A b$ stracts, 5, 78-82.

Langhout, D. J., J. B. Schutte, P. Van Leeuwen, J. Wiebenga \& S. Tamminga, 1999. Effect of dietary high and low methyllated citrus pectin on the activity of the ileal microflora and morphology of the small intestinal wall of broiler chickens. British Poultry Science, 40, 340-347.

Lubart, R., Y. Wollman, H. Friedmann, S. Rochkind \& I. Laulich, 1992. Effects of visible and near infra-red lasers on cell cultures. The Journal of Photochemistry and Photobiology B: Biology, 12, 305 310.

Maktabi, S., I. Watson \& R. Parton, 2011. Synergistic effect of UV, laser and microwave radiation or conventional heating on E. coli and on some spoilage and pathogenic bacteria. Innovative Food Science and Emerging Technologies, 12, 129-134.

Melnikova, I. M., V. S. Kuznetsov \& V. P. Anakumor, 1985. Preincubation irradation of duck eggs with a laser. Poultry Abstracts, 185, 75-77.

Mester, E. \& A. Mester, 1985. The biomedical effects of laser application. Lasers in Surgery and Medicine, 5, 31-39.

Moog, F., 1950. The functional differenttiation of the small intestine. I. The accumulation of alkaline phosphomonoesterase in the duodenum of the chick. Journal of Experimental Zoology, 115, 109-130.

Moore, P., T. D. Ridgway, R. G. Higbee \& E. W. Howard, 2005. Effect of wavelength on low-intensity laser irradiation-stimulated cell proliferation in vitro. Lasers in Surgery and Medicine, 36, 8-12.

Nigel, W., F. Wiling \& F. H. Schmidt, 1964. Fur de Aminosaurrearylamidase (sog. Leucine amino peptidase) Aktivitat in menschlichen serum. Die Wiener Klinische Wochenschrift, 42, 447-449.

Ninomiya, T, Y. Miyamoto, T. Ito, A. Yamashita, M. Wakita \& T. Nishisaka, 2003. High-intensity pulsed laser irradiation accelerates bone formation in metaphyseal trabecular bone in rat femur. Journal of Bone and Mineral Metabolism, 21, 67-73.

Nordstrom, C. \& A. Dahlqvist, 1973. Quantitative distribution of some enzymes along the villi and crypts of human small intestine. Scandinavian Journal of Gastroenterology, 8, 406-416. 
Effects of pre-incubation laser irradiation on hatchability and small intestine enzymes activity in ....

Obst, B. S. \& J. Diamond, 1992. Ontogenesis of intestinal nutrient transport in domestic chickens (Gallus Gallus) and its relation to growth. The Auk, 109, 451-464.

Olanrewaju, H. A., J. P. Thaxton, W. A. Dozier, J. Purswell, W. B. Roush \& S. L. Branton, 2006. A review of lighting programs for broiler production. International Journal of Poultry Science, 5, 301-308.

Oliveira-Junior, M. C., A. S. Monteiro, E. C. Leal-Junior, E. Munin, R. A. Osório, W. Ribeiro \& R. P. Vieira, 2013. Low-level laser therapy ameliorates CCl4-induced liver cirrhosis in rats. The Journal of Photochemistry and Photobiology, 89, 173178.

Ouf, S. A., A. Q. Alsarrani, A. A. Al-adly \& M. K. Ibrahim, 2012. Evaluation of lowintensity laser radiation on stimulating the cholesterol degrading activity. Part I. Microorganisms isolated from cholesterolrich materials. Saudi Journal of Biological Sciences, 19, 185-193.

Pesti, G. M., B. R. Miller \& J. Hargrave, 1992. User-Friendly Feed Formulation, Done Again (UFFDA). Programed by J. Hargrave. University of Georgia, USA.

Ruttanavut, J., K. Yamauchi, H. Goto \& T. Erikawa, 2009. Effects of dietary bamboo charcoal powder including vinegar liquid on growth performance and histological intestinal change in aigamo ducks. International Journal of Poultry Science, 8, 229-236.

Shin, B. L., Y. H. Chen \& J. C. Hsu, 2013. Morphological development of the small intestine in white Roman goslings. African Journal of Biotechnology, 12, 611-617.

Teshfam, M., 1984. Comparison of the effects of the high-acid milk replacer with conventional skim milk replacer. Ph.D. Thesis, University of Bristol, UK.

Van der Flier, L. G. \& H. Clevers, 2009. Stem cells, self-renewal, and differentiation in the intestinal epithelium. The Annual Review of Physiology, 71, 241-260.

Watanabe, N., S. Kamei, A. Ohkubo, M. Yamanaka, S. Ohsawa, K. Makino \& K. To- kuda, 1986. Urinary protein as measured with a pyrogallol red-molybdate complex, manually and in a Hitachi 726 automated analyzer. Clinical Chemistry, 32, 15511554.

Yakimenko, I., A. Ruban, R. Shevchenko \& V. Besulin, 1997. The role of impedancemethod in estimation of hen embryo development. Bulletin of BTSAU, 2, Bila Tserkva, pp. 247-250. (in Ukrainian).

Yakimenko, I., Besulin, V. \& A. Testik, 2002. The effects of low intensity red laser irradiation on hatching eggs in chicken and quail. International Journal of Poultry Science, 1, 6-8.

Yakovlev, A. F., G. N. Vyaizenen, G. P. Kosyakova, D. I. Shkurko \& S. N. Proshin, 2007. The Effect of short-term pulse laser irradiation of incubatory eggs on genome destabilization in broiler chickens. Russian Agricultural Science, 1, 44-45.

Yu, M., J. O. Naim \& R. J. Lanzafama, 1994. The effects of photo-irradiation on the secretion of TGF and PDGF from fibroblasts in vitro. Lasers in Surgery and Medicine, 6 (Suppl.), 8.

Paper received 14.04.2014; accepted for publication 13.06.2014

\section{Correspondence:}

J. Ghiasi Ghalehkandi

Department of Veterinary Medicine,

Shabestar Branch, Islamic Azad University,

Shabestar, Iran

e-mail: ghiasi_jam@yahoo.com 